Décadrages Décadrages

cınéma, à travers champs Cinéma, à travers champs

$7 \mid 2006$

Stephen Dwoskin

Le Souffle du désert (François Kohler, 2005)

Alain Boillat

(2) OpenEdition

Journals

Édition électronique

URL : http://journals.openedition.org/decadrages/492

DOI : $10.4000 /$ decadrages.492

ISSN : 2297-5977

Éditeur

Association Décadrages

Édition imprimée

Date de publication : 10 avril 2006

Pagination : 128-129

ISBN : 978-29700582-3-6

ISSN : 2235-7823

Référence électronique

Alain Boillat, «Le Souffle du désert (François Kohler, 2005) », Décadrages [En ligne], 7 | 2006, mis en ligne le 31 janvier 2014, consulté le 19 avril 2019. URL : http://journals.openedition.org/ decadrages/492 ; DOI : 10.4000/decadrages.492

Ce document a été généré automatiquement le 19 avril 2019

(B) Décadrages 


\title{
Le Souffle du désert (François Kohler, 2005)
}

\author{
Alain Boillat
}

1 Une marche de deux semaines est organisée à travers le Sahara tunisien ; treize hommes y participent, invités à méditer sur la question de la virilité, sur leur statut de fils, de père et de mari. Ceux qui participent à ce périple à la fois physique et intérieur se livrent avec authenticité et examinent leur existence avec une acuité qui confèrent à leur témoignage un véritable intérêt, permettant de développer, grâce à la multiplication des points de vue, une réflexion apparemment universelle sur la question de la masculinité. En effet, le film ne se réduit pas à une série de cures psychanalytiques offertes en pâture à un spectateur-voyeur féru de télé-réalité, même s'il est évident que l'« intimité surexposée » qui caractérise pour Serge Tisseron notre ère de l'audiovisuel influence le "dispositif » mis en œuvre par Kohler et le pacte qu'il a passé avec les intervenants. Parcours de vie, trajet parmi les dunes et cheminement dans la découverte de soi se superposent et donnent au film sa structure : l'organisation de l'itinéraire et des activités définissent des étapes qui sont autant de phases dans le "scénario " d'un film qui s'articule sur le dévoilement progressif des participants, ceux-ci allant même jusqu'à se «mettre à nu » dans le sens le plus littéral du terme. Bien sûr, la pertinence des confidences résulte du choix des personnes filmées qui, toutes francophones, sont habituées à la verbalisation des émotions : on ne trouvera donc nullement un panel révélateur des différentes classes sociales, ce qui réduit la portée sociologique de l'entreprise, ou du moins la limite (sans que cela ne soit thématisé) à une certaine catégorie d'individus. 